\title{
NONLINEAR STATIC ANALYSIS OF MASONRY BUILDINGS THROUGH FIBRE-BASED CAPACITY MODELLING
}

\author{
E. Acconcia, V. Buonocunto, F. Parisi \\ Department of Structures for Engineering and Architecture, University of Naples Federico II \\ Via Claudio 21, 80125 Naples, Italy \\ e-mail: elia.acconcia@unina.it, valentina.b.707@gmail.com,fulvio.parisi@unina.it
}

\begin{abstract}
Seismic performance assessment of masonry buildings requires a nonlinear response analysis to achieve a reliable understanding of the possible effects of future earthquakes in terms of damage and losses. Equivalent frame (EF) modelling combined with nonlinear static procedures has been recognized as an efficient tool, which was validated in several studies through both experimental data and post-earthquake damage inspections.

In this paper, a new macroelement based on a fibre formulation is implemented into a matrix analysis approach to build up a nonlinear EF model and to perform incremental static (pushover) analysis with response control. For each step of the analysis, the stiffness matrix of the structure is updated using the novel macroelement model, accounting for geometric and mechanical nonlinearities both in terms of flexural and shear behaviour. Floor systems are modelled with truss elements, the stiffness of which can be varied in order to consider either rigid or flexible floors. In addition, the capacity model can simulate different degrees of connection at wall intersections and can easily be adapted to consider structural elements made of reinforced concrete, steel, wood, or other materials.

The capacity modelling procedure proposed in this study was first validated by simulating the in-plane lateral behaviour of a full-scale masonry wall with opening, and then, implemented to run pushover analysis of existing masonry buildings representative of those located in the Campania region (southern Italy).
\end{abstract}

Keywords: Masonry buildings, Macroelement modelling, Fibre formulation, Experimental validation, Nonlinear static analysis, Seismic performance. 


\section{INTRODUCTION}

Post-earthquake reconnaissance missions and experimental programs have shown a significant vulnerability of unreinforced masonry (URM) structures to earthquakes, resulting in huge losses of life and money [1]. Despite the wide use of masonry as the oldest construction technology worldwide, the simulation of the seismic behaviour of URM structures and their retrofitting still need to be further investigated.

Over the years, various approaches have been proposed for simulation of URM structures, simplifying the problem differently according to the type of construction (e.g., modern or historical building, church, castle, bridge), specific purpose of the analysis (e.g., structural performance assessment under gravity loads, seismic actions, settlements), and the expected accuracy level and resolution of mechanical behaviour. Accurate results can be obtained through finite element (FE) simulation based on micro-modelling techniques, where masonry units, mortar joints and, if any, unit-mortar interfaces are distinctly modelled with nonlinear finite elements [2-5]. Several authors have proposed simplified micro-models in which only masonry units and joints are considered [6,7]. Even though micro-modelling techniques allow accurate simulations of masonry structures, they require a detailed knowledge of masonry constituents and have a considerable computational cost. This is a major drawback that makes FE micro-modelling rather difficult to apply in engineering practice and/or in structural assessments based on few data. In this respect, the macro-modelling approach [2] based on the assumption of masonry as equivalent homogeneous material allows a good trade-off between computational accuracy and cost, hence being applicable to real constructions and/or structures with few known properties.

An alternative computational strategy for structural response analysis of URM constructions, particularly in the case of buildings for their global seismic performance assessment, is based on macroelement modelling of walls with openings, i.e., the idealization of each wall as an equivalent frame (EF) with vertical and horizontal elements simulating pier and spandrel panels, respectively [8,9]. Macroelements with different behavioural modes can be used to model such types of masonry panels, which have comparable size with respect to openings. Pier-spandrel joint panels can be implicitly considered within the EF model, making use of macroelements with rigid parts at their ends. Macroelement modelling was validated on several structures, including those having an irregular layout of openings [10].

This paper presents a novel macroelement modelling procedure that permits the seismic analysis of masonry buildings, simulating the in-plane nonlinear response of load-bearing walls. The proposed macroelement, which is based on a fibre formulation, was validated in a previous study against experimental tests on single piers. In this study, the macroelement is implemented into a matrix-based formulation for development of EF models and their seismic performance assessment via nonlinear incremental static (pushover) analysis with response control. The overall approach is then validated at the system scale by comparing numerical results to experimental data of a lateral loading test on a full-scale masonry wall with central opening. The final part of this paper describes the application of the fibre-based macroelement approach to an URM structure representative of real buildings located in Campania (Italy), for their seismic fragility assessment.

\section{MACROELEMENT ANALYSIS PROCEDURE}

This study builds upon a fibre-based macroelement that was recently developed and experimentally validated by Parisi and Acconcia [11,12]. The aim was to develop a matrix-based procedure for nonlinear incremental static (pushover) analysis of masonry walls and buildings. 
The macroelement allows the simulation of flexural, shear and rocking contributions to deformations associated with in-plane lateral loading, considering geometric and mechanical nonlinearity sources as well as the macroscopic constitutive behaviour of masonry.

The pushover analysis procedure is based on a nonlinear incremental algorithm with response control, namely, where the structure is subjected to increasing horizontal displacement of a control point located at the roof level. The macroelement proposed by Parisi and Acconcia [12] is modified to incorporate the presence of possible rigid end parts, simulating the presence of pier-spandrel joint panels. Each macroelement is formulated according to Timoshenko's beam theory and its stiffness matrix is defined by accounting for axial, flexural, shear, and torsional behaviour. The stiffness matrix of the structure is then assembled and updated according to the secant method during pushover analysis. The stiffness matrix coefficients are indeed a function of the displacement components at the two ends of the macroelement. In each analysis step, the secant stiffness matrix is evaluated through an iterative procedure that can be summarized in the following phases:

- linearized solution of the structure under the displacements imposed in the current step;

- evaluation of the displacements experienced by each macroelement and corresponding stresses and strains throughout fibres;

- computation of the secant stiffness for each macroelement;

- linearized solution of the structure based on the updated stiffness matrix;

- convergence check in terms of internal forces for each macroelement;

- iteration of previous steps or termination of stiffness matrix updating.

In the following sections, the EF modelling and analysis algorithm is validated by comparing pushover analysis results to experimental data in the case of a full-scale tuff stone masonry wall [13]. The procedure is then used to build up the EF model of an URM building, the seismic vulnerability of which is evaluated through fragility analysis.

\section{EXPERIMENTAL VALIDATION AT SYSTEM SCALE}

The EF modelling approach and pushover analysis procedure was validated against a lateral loading test on a full-scale URM wall with central opening [13]. The wall specimen consisted of two piers connected to each other by a spandrel with timber lintel above the opening (Fig. 1). The wall was made of tuff stone masonry with running bond and 10-mm-thick mortar joints. Overall, the wall was 5.10-m-long, 3.62-m-high, and 310-mm-thick. The piers were 1.70-mlong, whereas the spandrel was 1-m-high. The specimen was first subjected to vertical loads on top of the piers and then to horizontal loading with displacement control. Vertical loads had an intensity of $200 \mathrm{kN}$. The horizontal load consisted of a displacement-controlled force that was applied to the wall at a height of approximately $3.00 \mathrm{~m}$ from the base of the piers. The tuff masonry was composed of yellow tuff stones and a pozzolanic mortar, having the mechanical properties listed in Table 1. 

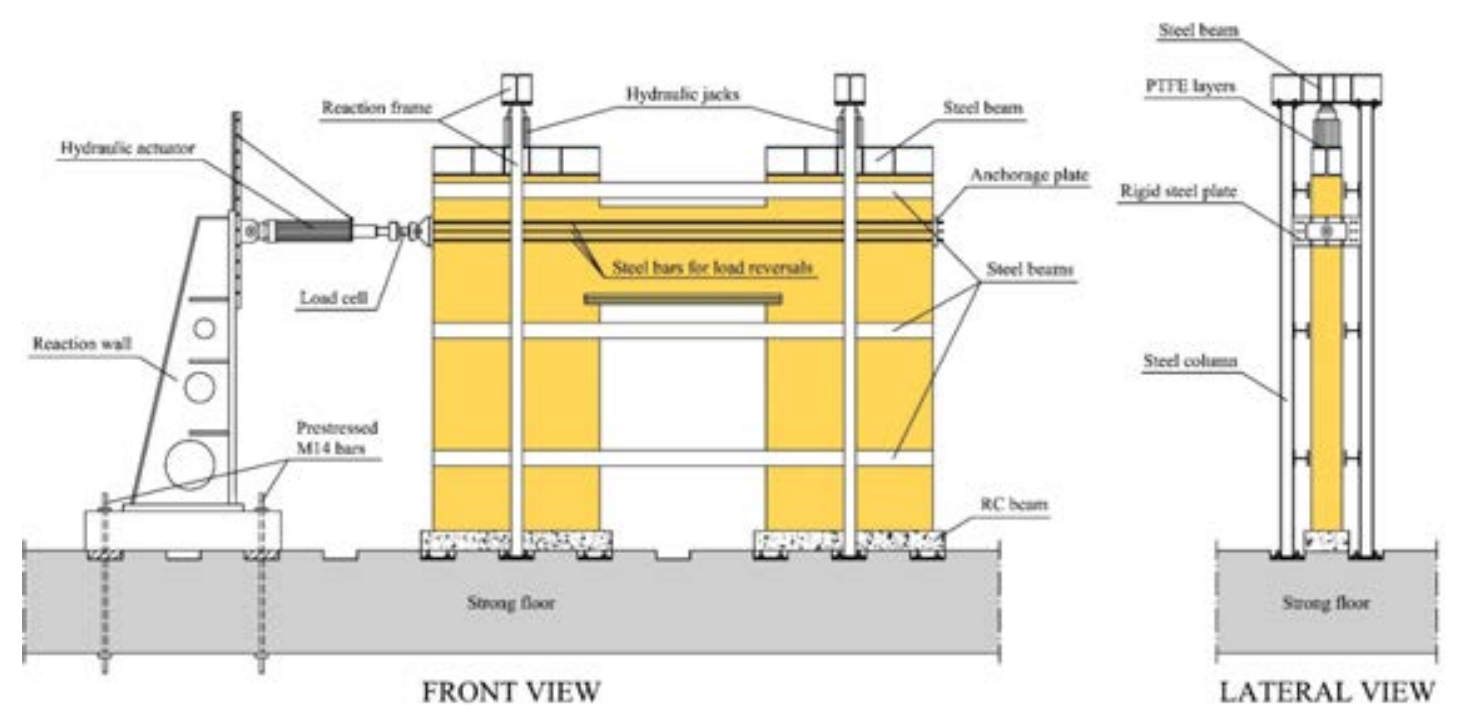

Figure 1: Experimental setup of lateral loading test on full-scale URM wall with opening [13].

\begin{tabular}{lcccc}
\hline Material & $\begin{array}{c}\text { Tensile } \\
\text { strength } f_{t} \\
{[\mathrm{MPa}]}\end{array}$ & $\begin{array}{c}\text { Compressive } \\
\text { strength } f_{c} \\
{[\mathrm{MPa}]}\end{array}$ & $\begin{array}{c}\text { Young's } \\
\text { modulus } E \\
{[\mathrm{GPa}]}\end{array}$ & $\begin{array}{c}\text { Shear } \\
\text { modulus } G \\
{[\mathrm{GPa}]}\end{array}$ \\
\hline $\begin{array}{l}\text { Tuff masonry under com- } \\
\text { pression parallel to mortar }\end{array}$ & 0.192 & 3.85 & 2.07 & 0.86 \\
$\begin{array}{l}\text { bed joints (case of span- } \\
\text { drel) }\end{array}$ & & & & \\
$\begin{array}{l}\text { Tuff masonry under com- } \\
\text { pression perpendicular to } \\
\text { mortar bed joints (case of } \\
\text { piers) }\end{array}$ & 0.198 & 3.96 & 2.22 & 0.92 \\
\hline
\end{tabular}

Table 1: Mechanical properties of tuff stone masonry.

Figures $2 \mathrm{a}$ and $2 \mathrm{~b}$ show the EF model of the wall specimen and a numerical-experimental comparison in terms of base shear versus top displacement curves, respectively. The numerical procedure allows a satisfactory reproduction of the initial stiffness, the peak base shear (experimental value of $184.31 \mathrm{kN}$ against numerical value of $182.96 \mathrm{kN}$ ), and maximum lateral displacement. The damage observed on the wall specimen at the end of test was also well simulated, indicating a flexural failure of both piers and a diagonal shear cracking in the spandrel. 




(a)

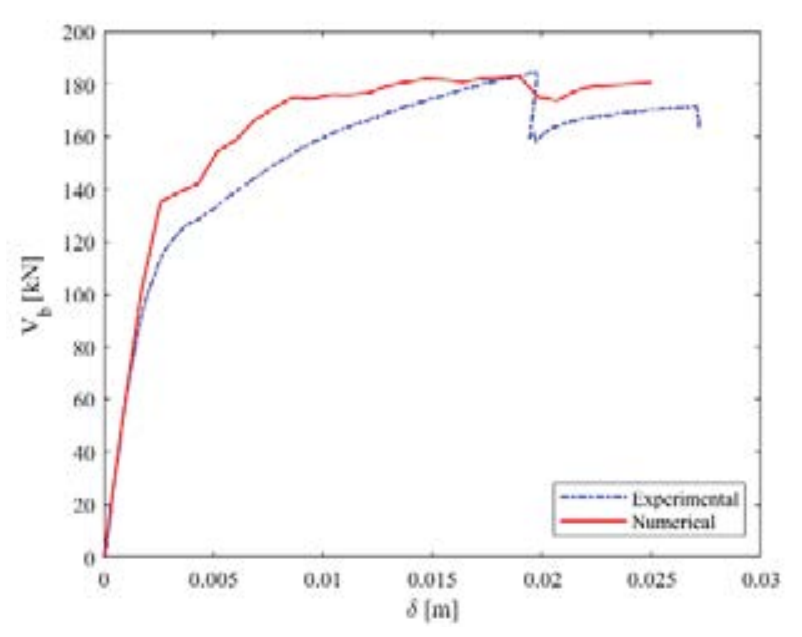

(b)

Figure 2: (a) EF model of wall specimen; (b) numerical-experimental comparison in terms of base shear versus top displacement curve.

\section{FRAGILITY ANALYSIS OF CASE-STUDY BUILDINGS}

The definition of case studies was based upon typological-structural data regarding existing URM buildings in the Campania region (Italy), in order to generate a sample of archetype buildings representative of residential buildings surveyed in that area. In detail, reference was made to real data from the CARTIS database [15], which collects information on typological and geometric characteristics of Italian buildings. Based on the 2011 Italian census data [16], the Campania region is characterized for more than $47 \%$ by masonry buildings, $94 \%$ of which were built before the first Italian code on masonry structures, namely DM 20/11/1987 [17]. In terms of size distribution, the masonry buildings in the area are composed of single-storey buildings (19\%), two-storey buildings (45\%), three-storey buildings (22\%), and buildings with more than three storeys (14\%).

By querying the CARTIS database [15], the pre-code building class in the area under study was characterized in more detail. It was found that $57.9 \%$ of existing buildings are made of tuff stone masonry with load-bearing walls having the following distribution of thickness at the ground floor: $700 \mathrm{~mm}$ in $32.9 \%$ of cases and $800 \mathrm{~mm}$ in $39.4 \%$, with remaining values equal to 400,500 and $600 \mathrm{~mm}$. The mean thickness of load-bearing walls at the ground floor is $660 \mathrm{~mm}$. In plan, the on-centre distance between walls was found to be $4.50 \mathrm{~m}$ in $80.2 \%$ of cases, $5.0 \mathrm{~m}$ in $15.3 \%$, and $4.0 \mathrm{~m}$ in $4.5 \%$, with a mean value of $4.64 \mathrm{~m}$. The mean floor area of buildings falls in the interval $\left[100 \mathrm{~m}^{2}, 150 \mathrm{~m}^{2}\right]$ in $41 \%$ of cases, $\left[60 \mathrm{~m}^{2}, 100 \mathrm{~m}^{2}\right]$ in $24 \%,\left[150 \mathrm{~m}^{2}, 250\right.$ $\left.\mathrm{m}^{2}\right]$ in $28 \%$, and $\left[250 \mathrm{~m}^{2}, 350 \mathrm{~m}^{2}\right]$ in $3 \%$, with the remaining $4 \%$ of buildings having an area larger than $350 \mathrm{~m}^{2}$. The mean floor area is $159 \mathrm{~m}^{2}$. It was also found that $79 \%$ of tuff stone masonry buildings have flat floors, whereas the remaining $21 \%$ of them is characterized by vaults. Among flat floors, there are $68 \%$ of them consisting of steel I-beams and hollow tiles, $14 \%$ made of wooden beams, $12 \%$ made of concrete and hollow tiles, $5 \%$ consisting of wooden beams and tiles, and 1\% made of SAP-type prefabricated systems with steel-reinforced tiles. The selected building has a rectangular plan with 3 walls in the X direction and 5 walls in the Y direction and consists of 2 floors (Fig. 3). The geometric characteristics agree with statistics reported above, so the distance between walls is approximately $4.60 \mathrm{~m}$, the thickness of walls 
at the ground floor is $660 \mathrm{~mm}$, reducing to $500 \mathrm{~mm}$ at the first floor. The floors have an area of $246 \mathrm{~m}^{2}$ and consist of steel I-beams and hollow clay tiles.

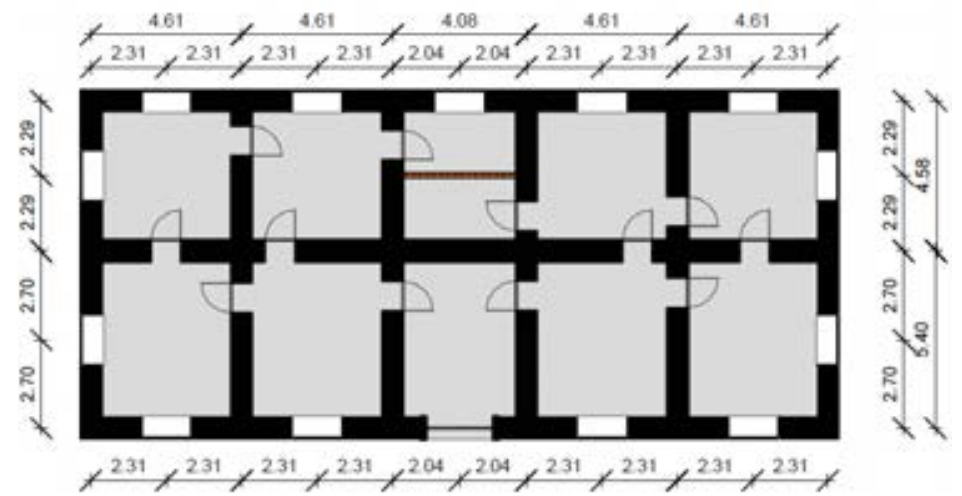

Figure 3: Plan of the building (longitudinal and transverse walls in the $\mathrm{X}$ and $\mathrm{Y}$ directions, respectively).

As regards the mechanical characteristics, the tuff stone masonry under study was regarded as 'regular soft stone masonry' according to the Italian building code NTC 2018 [18]. The mean values of mechanical properties assumed here were set to the average of those provided by the Italian building code commentary CS.LL.PP. 21/01/2019 n.7 [19]. According to CNR-DT 2122013 guidelines on seismic reliability assessment of existing buildings [20] and previous studies $[7,14]$, uncertainties in material properties were modelled as outlined in Table 2, defining the dispersion of lognormally distributed variables as follows:

$$
\beta=\frac{X_{\max }-X_{\min }}{2}
$$

where $X_{\min }$ and $X_{\max }$ are the minimum and maximum values of the natural logarithms of the property.

\begin{tabular}{|c|c|c|c|c|c|c|c|}
\hline \multirow[t]{2}{*}{ Property } & \multirow[t]{2}{*}{ Symbol } & \multirow[t]{2}{*}{ Unit } & \multicolumn{2}{|c|}{ Range } & \multirow[t]{2}{*}{ Distribution } & \multirow[t]{2}{*}{$\mu$} & \multirow[t]{2}{*}{$\beta$} \\
\hline & & & $\min$ & $\max$ & & & \\
\hline Compressive strength & $f_{m}$ & $\mathrm{MPa}$ & 2.00 & 3.20 & Lognormal & 2.60 & 0.24 \\
\hline Diagonal shear strength & $\tau_{0}$ & $\mathrm{MPa}$ & 0.04 & 0.08 & Lognormal & 0.06 & 0.35 \\
\hline Sliding shear strength & $f_{v 0}$ & $\mathrm{MPa}$ & 0.10 & 0.19 & Deterministic & 0.145 & - \\
\hline Young's modulus & $E$ & $\mathrm{MPa}$ & 1200 & 1620 & Lognormal & 1410 & 0.15 \\
\hline Shear modulus & $G$ & $\mathrm{MPa}$ & 400 & 500 & Lognormal & $0.33 E$ & - \\
\hline Tensile strength & $f_{t}$ & $\mathrm{MPa}$ & - & - & Lognormal & $0.05 f_{m}$ & - \\
\hline Tensile fracture energy & $G_{f t}$ & $\mathrm{~N} / \mathrm{mm}$ & - & - & Deterministic & 0.0025 & - \\
\hline Specific weight & $w$ & $\mathrm{kN} / \mathrm{m}^{3}$ & - & - & Deterministic & 16 & - \\
\hline
\end{tabular}

Table 2: Uncertainty modelling of material properties.

As regards the mechanical modelling of masonry, the compressive behaviour was simulated by assigning the constitutive model proposed by Augenti and Parisi [21]. That model is defined by the peak compressive strength $f_{m}$ and the corresponding axial strain, which was assumed so that the secant modulus of elasticity at $0.3 f_{m}$ was equal to Young's modulus $E$ provided in [19]. The tensile behaviour of masonry was assumed to be linear elastic up to the peak strength $f_{t}$ and 
followed by an exponential post-peak phase, assuming $f_{t}=0.05 f_{m}$ and a deterministic value of tensile fracture energy $G_{f t}=0.0025 \mathrm{~N} / \mathrm{mm}$.

The selected building was analysed through an equivalent frame model (Fig. 4) in which macro-elements were equipped with rigid offsets suitably sized to take into account the pierspandrel joint flexibility and interaction according to previous studies [10,22]. Floor systems were modelled through linear truss elements with axial stiffness derived from size and material properties. That modus operandi allowed on one hand the floor flexibility to be considered in the distribution of horizontal actions between walls, and on the other, the axial force in spandrels to be computed. By the way, the flange effect due to wall-to-wall connections was taken into account in the structural model. It is also noted that one-way floors were assumed to span in the $\mathrm{Y}$ direction of the building plan, hence transmitting gravity loads to walls oriented in the $\mathrm{X}$ direction. Therefore, the gravity loads on walls in the $\mathrm{Y}$ direction were barely associated with self-weight of structural elements. Pushover analysis was performed with response control under two lateral load profiles, namely, the 'modal profile' with lateral forces proportional to the first vibration mode times inertia masses and the 'mass profile' proportional to inertia masses only. The centre of mass at the roof level was assumed as control point for nonlinear seismic analysis.

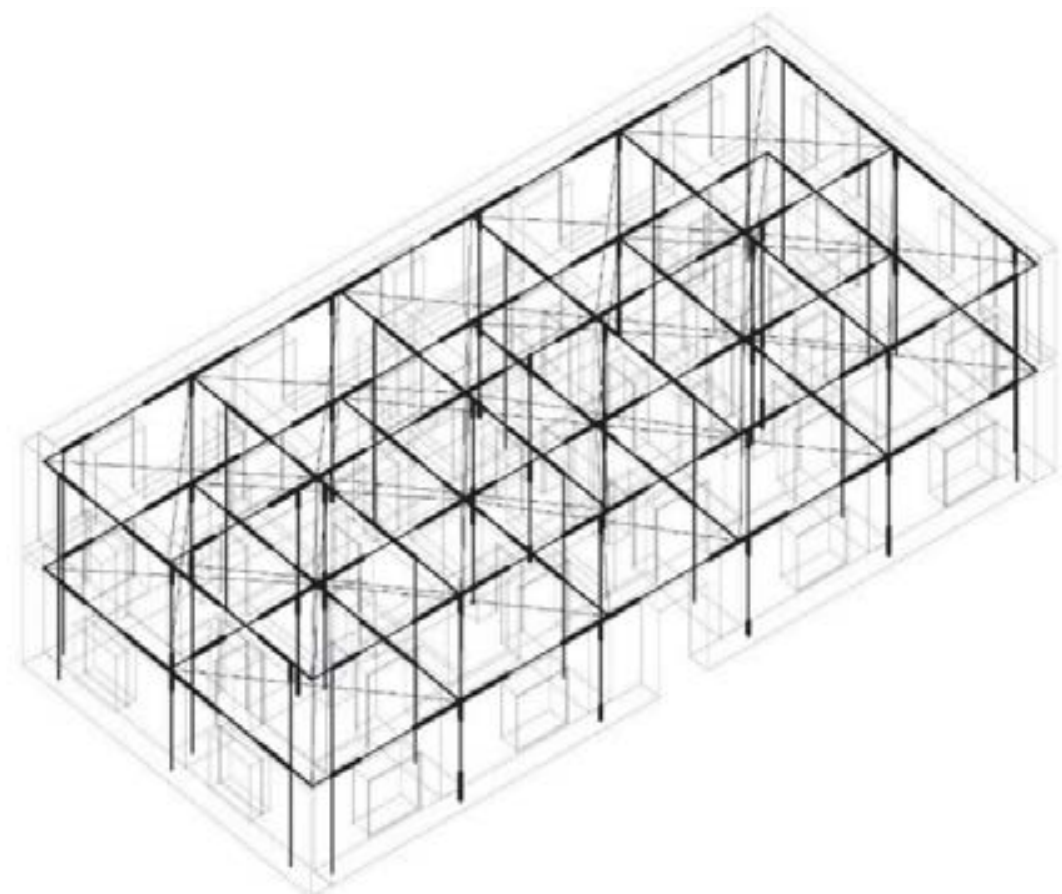

Figure 4: Equivalent frame model of the cases-study building.

Fragility analysis was carried out on 27 structural models of the building, corresponding to as many samples of material properties assumed to be lognormally distributed according to Table 2. More specifically, three possible values equal to $\mu, \mu \mathrm{e}^{-\beta}\left(16^{\text {th }}\right.$ percentile $)$ and $\mu \mathrm{e}^{+\beta}\left(84^{\text {th }}\right.$ percentile) were assigned to $f_{m}, \tau_{0}$ and $E$, resulting in $3^{3}$ combinations of those material properties. Figure 4 shows the capacity curves corresponding to each direction and profile of horizontal forces. 




(a)



(c)

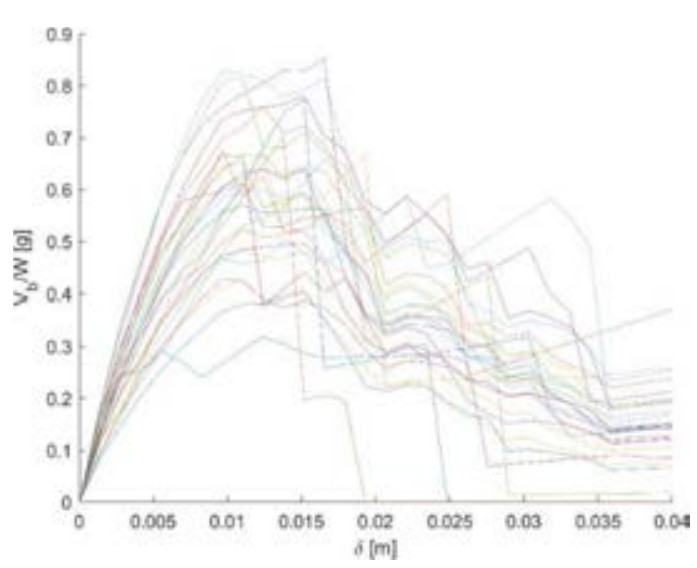

(b)

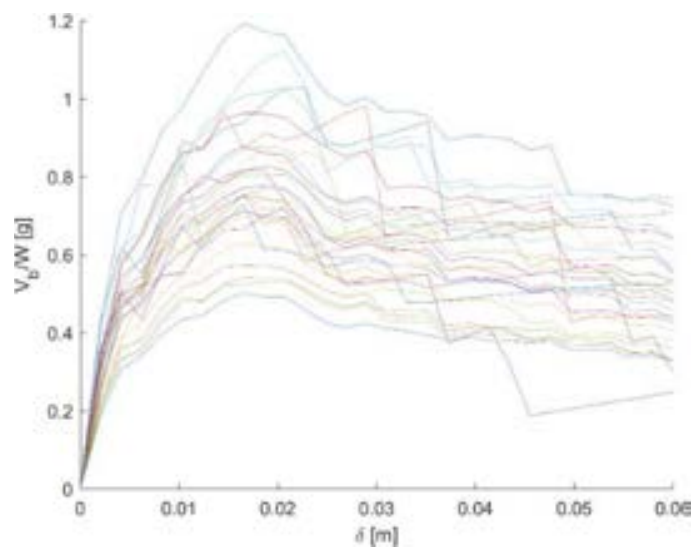

(c)

Figure 4: Pushover capacity curves of case-study building: (a) X direction and modal profile; (b) X direction and mass profile; (c) Y direction and modal profile; (d) Y direction and mass profile.

Seismic demand was evaluated in accordance with the N2 method [23], allowing global safety checking in terms of displacement. The building was assumed to be located on ground type A, i.e., rock or rock-like soil. Damage assessment was then performed with respect to four damage states (DSs), allowing seismic fragility associated with each DS to be computed under varying peak ground acceleration (PGA) that was assumed as intensity measure. The following DSs were considered: slight damage (DS1) associated with $60 \%$ of the maximum base shear; moderate damage (DS2) associated with the maximum base shear; extensive damage (DS3) associated with $20 \%$ post-peak degradation of base shear; collapse (DS4) corresponding to $50 \%$ post-peak degradation of base shear.

After that fragility points were individually derived, a lognormal probability distribution was fitted to them. The total dispersion was computed as square root of the sum of squares of dispersion associated with capacity (i.e., dispersion derived via fitting) and dispersion associated with demand, the latter set equal to 0.4 .

Figures 5 and 6 show that the seismic fragility of the building was rather insensitive to the lateral load profile, while highlighting a significant sensitivity to the orientation of seismic actions. Indeed, the highest fragility of the structure is related to the Y direction, as expected according to the lowest intensity of gravity loads on walls parallel to one-way floors. 


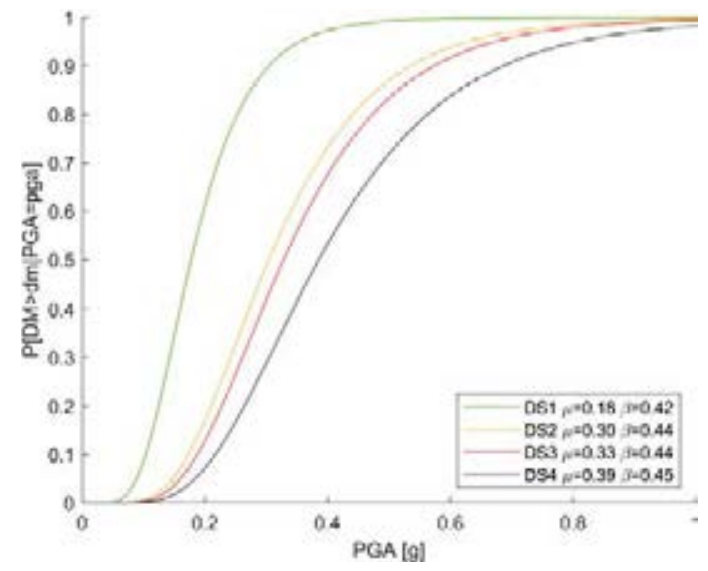

(a)

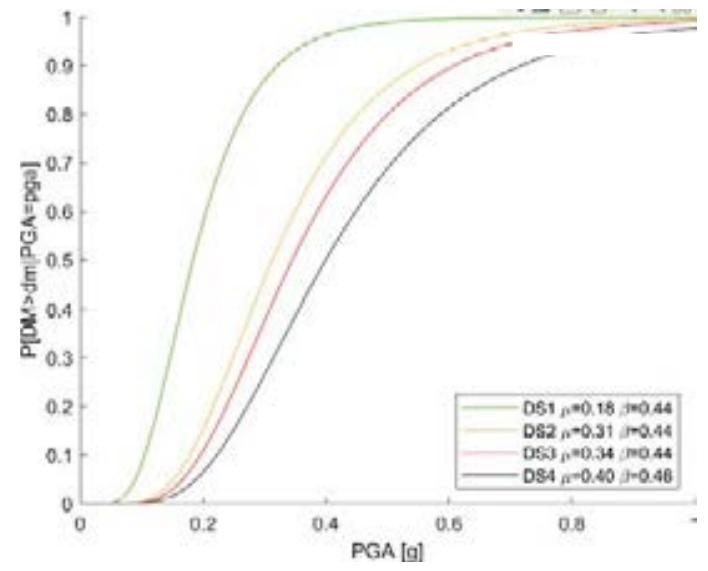

(b)

Figure 3: Fragility curves in the $\mathrm{X}$ direction: (a) modal profile; (b) mass profile.



(a)

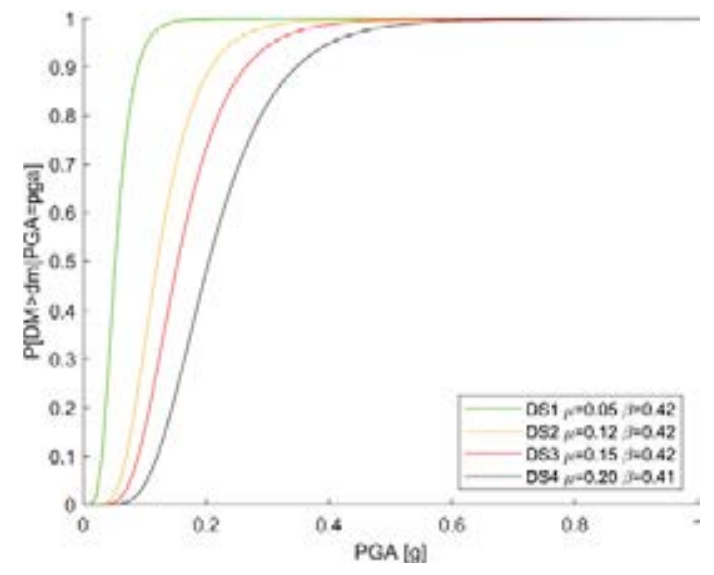

(b)

Figure 4: Fragility curves in the Y direction: (a) modal profile; (b) mass profile.

\section{CONCLUSIONS}

In this paper, a novel macroelement modelling procedure for masonry buildings has been presented and experimentally validated, creating the basis for efficient computation of seismic fragility through pushover analysis with response control. The macroelement modelling procedure is based on the fibre modelling approach and is framed within a matrix analysis approach, allowing consideration of material nonlinearities and real construction features (e.g. wall-towall connections, floor flexibility, presence of lintels). The macroelement modelling procedure build upon a macroelement that was originally validated against an experimental test on piers, and then it was extended to the structural system scale. Therefore, the matrix-based analysis procedure was validated against experimental data of a lateral load test on a full-scale masonry wall with central opening, highlighting a satisfactory numerical-experimental agreement.

The final part of this paper has presented the implementation of the proposed procedure in the seismic vulnerability assessment of a masonry building. The building geometry was modelled according to statistical data on existing masonry buildings located in the Campania region, Italy. Uncertainties in material properties were modelled and propagated through pushover 
analysis, considering 27 samples of the building. Assuming four damage states corresponding to as many performance levels of the building, fragility curves were obtained to provide the conditional probability of exceeding each damage state given seismic intensity, which was measured in terms of peak ground acceleration.

The output of this study can be of interest for seismic risk assessments at regional scale and can be extended to other geometric configurations, types, and classes of masonry buildings at national scale. The fragility curves presented in this paper will be compared to those derived through Monte Carlo simulation, assessing the influence of the uncertainty in capacity that is usually of paramount importance particularly in the case of existing masonry buildings. Further developments of this study will also include a computationally efficient computation of the uncertainty in seismic demand, using nonlinear time history analysis of equivalent elastic-plastic oscillators associated with the pushover curves of the building samples.

\section{REFERENCES}

[1] F. Parisi, N. Augenti, Earthquake damages to cultural heritage constructions and simplified assessment of artworks. Engineering Failure Analysis, 34, 735-760, 2013.

[2] P.B. Lourenço, Computational strategies for masonry structures. PhD thesis, Delft University Press, 1996.

[3] A.W. Page, Finite element model for masonry. Journal of Structural Division, 104(8), 1267-1285, 1978.

[4] P.B. Lourenço, J.G. Rots, Multisurface interface model for the analysis of masonry structures. Journal of Structural Engineering, 123(7), 660-668, 1997.

[5] F. Parisi, C. Balestrieri, D. Asprone, Nonlinear micromechanical model for tuff stone masonry: Experimental validation and performance limit states. Construction and Building Materials, 105, 165-175, 2016.

[6] F. Parisi, G.P. Lignola, N. Augenti, A. Prota, G. Manfredi, Rocking response assessment of in-plane laterally-loaded masonry walls with openings. Engineering Structures, 56, 1234-1248, 2013.

[7] F. Parisi, G.P. Lignola, N. Augenti, A. Prota, G. Manfredi, Nonlinear behavior of a masonry sub-assemblage before and after strengthening with inorganic matrix-grid composites. Journal of Composites for Construction, 15(5), 821-832, 2011.

[8] F. Parisi F., Seismic design of box-type unreinforced masonry buildings through direct displacement-based approach. The Open Construction \& Building Technology Journal, 10(Suppl 2: M9), 293-311, 2016.

[9] N. Augenti, F. Parisi, Teoria e Tecnica delle Strutture in Muratura. Hoepli, 2019.

[10] F. Parisi, N. Augenti, Seismic capacity of irregular unreinforced masonry walls with openings. Earthquake Engineering and Structural Dynamics, 42(1), 101-121, 2013.

[11] F. Parisi, E. Acconcia, Fibre-based capacity model for URM piers subjected to combined in-plane and out-of-plane actions. $16^{\text {th }}$ European Conference on Earthquake Engineering, Thessaloniki, Greece, June 18-21, 2018.

[12] F. Parisi, E. Acconcia, Formulation and experimental validation of distributed plasticity macroelement for unreinforced masonry walls. J. Kubica, A. Kwiecień, Ł. Bednarz, eds. 
Brick and Block Masonry - From Historical to Sustainable Masonry, Proceedings of the 17th International Brick/Block Masonry Conference, Kraków, Poland, July 5-8, 2020.

[13] N. Augenti, F. Parisi, A. Prota, G. Manfredi, In-plane lateral response of a full-scale masonry subassemblage with and without an inorganic matrix-grid strengthening system. Journal of Composites for Construction, 15(4), 578-590, 2011.

[14] F. Parisi, G. Sabella, N. Augenti, Constitutive model selection for URM cross sections based on best-fit analytical moment-curvature diagrams. Engineering Structures, 111, 451-466, 2016.

[15] G. Zuccaro, M. Dolce, D. De Gregorio, E. Speranza, C. Moroni, La scheda CARTIS per la caratterizzazione tipologico- strutturale dei comparti urbani costituiti da edifici ordinari. Valutazione dell'esposizione in analisi di rischio sismico. $34^{\text {th }}$ National Conference GNGTS, Trieste, Italy, November 17-19, 2015.

[16] ISTAT. 15 th Italian national census of population. Italian National Institute of Statistics, 2011.

[17] D.M. 20/11/1987: Norme tecniche per la progettazione, esecuzione e collaudo degli edifici in muratura e per il loro consolidamento. Italian Ministry of Public Works, 1987.

[18] NTC 2018. D.M. 17/01/2018: Norme tecniche per le costruzioni. Ministry of Infrastructure and Transportation, 2018.

[19] CS.LL.PP. 21/01/2019 n.7: Istruzioni per l'applicazione dell'«Aggiornamento delle "Norme tecniche per le costruzioni"” di cui al decreto ministeriale 17 gennaio 2018. Ministry of Infrastructure and Transportation, 2019.

[20] CNR-DT 212-2013: Istruzioni per la valutazione affidabilistica della sicurezza sismica di edifici esistenti. Consiglio Nazionale delle Ricerche, 2014.

[21] N. Augenti, F. Parisi, Constitutive models for tuff masonry under uniaxial compression. Journal of Materials in Civil Engineering, 22(11), 1102-1111, 2010.

[22] M. Dolce, Schematizzazione e modellazione degli edifici in muratura soggetti ad azioni sismiche. L'Industria delle Costruzioni, 25(242), 44-57, 1991.

[23] P. Fajfar, P. Gašperšič, The N2 method for the seismic damage analysis of RC buildings. Earthquake Engineering and Structural Dynamics, 25, 31-46, 1996. 